\title{
Soil Application of Cow Dung with Foliar Application of Boost Extra, Effect on Growth and Yield of Okra in an Ultisol, Nigeria
}

\author{
Ogundare, S. K. \\ Kabba College of Agriculture, Division of Agricultural Colleges, Ahmadu Bello University, \\ Zaria, Nigeria \\ Mohammed, S. A. \\ Kabba College of Agriculture, Division of Agricultural Colleges, Ahmadu Bello University, \\ Zaria, Nigeria \\ Owolabi, J. F. \\ Kabba College of Agriculture, Division of Agricultural Colleges, Ahmadu Bello University, \\ Zaria, Nigeria
}

Received: September 29, 2015 Accepted: October 10, 2015 Published: November 16, 2015 doi:10.5296/jas.v4i1.8579

URL: http://dx.doi.org/10.5296/jas.v4i1.8579

\begin{abstract}
Experiments were carried out at the student's experimental field, Kabba College of Agriculture, Horticulture section to examine the effect of soil application of cow dung combined with foliar application of boost extra on growth and yield of okra in an ultisol, Nigeria. The land was ploughed each year and harrowed with the aid of tractor mounted implements. The experiment was laid out in a randomized complete block design (RCBD). The treatments consisted of $\mathrm{A}=3 \mathrm{t} / \mathrm{ha}$ cow dung, $\mathrm{B}=1.0 \mathrm{~L} / \mathrm{ha}$ foliar $+2.5 \mathrm{t} / \mathrm{ha}$ cow dung, $\mathrm{C}$ $=1.5 \mathrm{~L} / \mathrm{ha}$ foliar $+2 \mathrm{t} / \mathrm{ha}$ cow dung, $\mathrm{D}=2 \mathrm{~L} / \mathrm{ha}$ foliar $+1.5 \mathrm{t} / \mathrm{ha}$ cow dung, $\mathrm{E}=2.5 \mathrm{~L} / \mathrm{ha}$ foliar $+1.0 \mathrm{t} / \mathrm{ha}$ cow dung, $\mathrm{F}=3 \mathrm{t} / \mathrm{ha}$ foliar. Each year experiment was conducted using a single field having dimension of 35 by $14 \mathrm{~m}$ which was laid out into three blocks with $1 \mathrm{~m}$ guard row between blocks. Each block consists of six plots ( 5 by $4 \mathrm{~m}$ ) and $1 \mathrm{~m}$ guard row between plots. Cow dung manure was applied a week before planting. Okra variety Lady's finger was used. Three seeds per hole were planted on April $4^{\text {th }}$ in both years on the flat with a spacing of $60 \mathrm{~cm} \times 25 \mathrm{~cm}$ between and within the rows and later thinned to one plant per stand. Data taken included plant height at $50 \%$ flowering, number of branches per plant, leaf area, pod length, pod diameter, number of pods per plant; and pod weight and yield (t/ha). The data were subjected to Analysis of Variance (ANOVA) while the Least Significant Difference
\end{abstract}


(LSD) was used to separate treatment means. The result shows that plot treated with $2.0 \mathrm{~L} / \mathrm{ha}$ foliar $+1.5 \mathrm{t} / \mathrm{ha}$ cow dung had the best performance in yield and yield components in this study. It is therefore recommended that okra farmers should integrated foliar fertilizer (boost extra) at the rate of $2 \mathrm{~L}$ per hectare with cow dung at rate of $1.5 \mathrm{t}$ per hectare be used for okra production in the study area.

Keywords: Abelmochus esculentus, Lady finger, Malvaceae, Significant, Yield

\section{Introduction}

Okra (Abelmochus esculentus (L.) Moench is a member of the family Malvaceae (George 1999). It is usually grown in Nigeria primarily for its mucilaginous content. Pods and seeds are rich in phenolic compounds (Arapitsas, 2008). Fresh pods are low in calories, no fat, high in fiber, and have several valuable nutrients (NAP, 2006). Fresh okra pods are the most important vegetable source of viscous fiber, an important dietary component to lower cholesterol (Kendall and Jenkins, 2004). Seven-days-old fresh okra pods have the highest concentration of nutrients (Agbo et al., 2008). Potential of mucilage for medicinal applications includes uses as an extender of serum albumin (BeMiller et al., 1993), as tablet binder (Ofoefule et al., 2001) and as suspending agent in formulations (Kumar et al., 2009). Okra mucilage is used as a protective food additive against irritating and inflammatory gastric diseases (Lengsfelf et al., 2004).

Use of organic manures as a means of maintaining and increasing soil fertility has been advocated (Alasiri and Ogunkeye, 1999: Smil, 2000). Organic manures, when efficiently and effectively used, ensure sustainable crop productivities by immobilizing nutrients that are susceptible to leaching. Nutrients contained in manures are released more slowly and are stored for a longer time in the soil, ensuring longer residual effects. Improved root development and higher crop yields

(Sharma and Mittra, 1991: Abou El Magd et al., 2005). Manures are usually applied at higher rates, relative to inorganic fertilizers. When applied at high rate, they give residual effects on the growth and yield of succeeding crop (Makinde and Ayoola, 2008). Improvements of environmental conditions as well as the need to reduce cost of fertilizing crops are reasons for advocating use of organic materials (Bayu et al., 2006). Organic manures improve soil fertility by activating soil microbial biomass (Ayuso et al., 1996). Applications of manures sustain cropping system through better nutrient recycling (El-Shakweer et al., 1998). Manure provides a source of macro and micro nutrient in available forms, thereby improving physical and biological properties of the soil (Abou El-Magd et al., 2006). Long time use of cow dung increased aggregate stability, pore space, bulk density and available water range (Vanlauwe et al., 2001). Cow dung applied with inorganic nitrogen (N), increased soil $\mathrm{pH}$ and ameliorated acidity (Olayinka and Ailenubhi, 2001). Continous application of cow dung increased soil organic matter (Maestro et al., 2007), contents of available phosphorus and inorganic nitrogen (Zhao et al., 2009), soil cation exchange capacity (Yadev and Prasad, 1992).

Crop plants require 17 nutrients to complete their life cycle. Macronutrients are required in higher amounts compared to micronutrients. However, from the plant essentiality point of 
view, all the nutrients are equally important for plant growth. First three macronutrients $(\mathrm{C}, \mathrm{H}$ and $\mathrm{O}$ ) are supplied to plants by air and water. Hence, their supply to plants is not a problem. Hence, the remaining 14 nutrients should be present in the plant growth medium in adequate amount and proportion for plant growth (Fageria, 2007). Research on foliar fertilization was possibly started in the late 1940s and early 1950s (Fritz, 1978; Haq and Mallarino, 2000; Girma et al., 2007). Unlike many technologies, its pace followed an unpredictable sequence of events. In the early 1980s, studies on foliar application of fertilizers investigated for selected crops, including cereals (Girma et al., 2007). The practice of applying liquid fertilizer to plant leaves (foliar fertilization), is recently done in Nigeria, and it is gradually gaining popularity among peasant farmers in many cultivated crops. This method of fertilizer application has been reported to increase the growth, yield and quality of crops such as okra (Selvi and Rani, 2000), soybean (Barge, 2001) and tomato (Alexander et al., 2004) among others. Boost extra, is a foliar fertilizers that is commonly used by farmers in Nigeria. It is manufactured by Candel Company and contains both the macro and micro nutrients in various combinations $(20 \% \mathrm{~N}, \mathrm{P}$ and $\mathrm{K}, 0.075 \% \mathrm{Zn}, \mathrm{Cu}$ and $\mathrm{Mg}, 1.5 \% \mathrm{Fe}, 0.35 \% \mathrm{Mn}$, $0.035 \%$ Bo and $0.012 \%$ Mo with $\mathrm{pH}$ range of 4.0-4.5).

The objective of this research is to examine the effect of soil application of cow dung combined with foliar application of boost extra on growth and yield of okra in an ultisol, Nigeria

\section{Materials and Methods}

Experiments were carried out at the student's experimental field, Kabba College of Agriculture, Horticulture section. It is located in the southern guinea savannah agro ecological zone of Nigeria of $07^{0} 53^{\prime} \mathrm{N}, 06^{0} 08 \mathrm{E}$. Kabba has average rainfall of $1250 \mathrm{~mm}$ per year, temperature ranges from $18^{\circ} \mathrm{c}-32^{\circ} \mathrm{c}$. It also has the mean relative humidity (R.H) of about $59 \%$ and four hundred and twenty seven meters $(427 \mathrm{~m})$ above sea level, according to Kabba College of Agriculture Metrological Station, field survey, (2011).

\section{Field Work}

The land was ploughed each year and harrowed with the aid of tractor mounted implements. The experiment was laid out in a randomized complete block design (RCBD). The treatments consisted of $\mathrm{A}=3 \mathrm{t} / \mathrm{ha}$ cow dung, $\mathrm{B}=1 \mathrm{1} / \mathrm{ha}$ foliar $+2.5 \mathrm{t} / \mathrm{ha}$ cow dung, $\mathrm{C}=1.51 / \mathrm{ha}$ foliar + $2 \mathrm{t} / \mathrm{ha}$ cow dung, $\mathrm{D}=2 \mathrm{l} / \mathrm{ha}$ foliar $\quad+1.5 \mathrm{t} / \mathrm{ha}$ cow dung, $\mathrm{E}=2.5 \mathrm{l} / \mathrm{ha}$ foliar $+1 \mathrm{t} / \mathrm{ha}$ cow dung, $\mathrm{F}=3 \mathrm{t} / \mathrm{ha}$ foliar. Each year experiment was conducted using a single field having dimension of 35 by $14 \mathrm{~m}$ which was laid out into three blocks with $1 \mathrm{~m}$ guard row between blocks. Each block consists of six plots $(5$ by $4 \mathrm{~m})$ and $1 \mathrm{~m}$ guard row between plots. Cow dung manure was applied a week before planting. Okra variety Lady's finger was used. The seeds were treated with Peperomie pellucida leaf powder at $30 \mathrm{~g}$ per 100 seeds as recommended by Ibe et al. (1998) as quoted by Iyagba et al. (2012) to control disease causing organisms. Three seeds per hole were planted on April $4^{\text {th }}$ in both years on the flat with a spacing of $60 \mathrm{~cm}$ $\mathrm{x} 25 \mathrm{~cm}$ between and within the rows and later thinned to one plant/stand. The required quantity of foliar spray of boost extra in formulated concentrations $(20 \% \mathrm{~N}, \mathrm{P}$ and $\mathrm{K}, 0.075 \% \mathrm{Zn}, \mathrm{Cu}$ and $\mathrm{Mg}, 1.5 \% \mathrm{Fe}, 0.35 \% \mathrm{Mn}, 0.035 \%$ Bo and $0.012 \%$ Mo with $\mathrm{pH}$ range of 4.0-4.5) was 
applied to crop at 2, 4, 6 and 8 week after planting. The control treatment was sprayed with sole water. Weeding was done manually at 3 and 8 weeks after sowing. Ten plants were randomly selected at the centre of each plot for data collection.

\section{Soil Sampling and Analysis}

Before the commencement of the experiment in 2014, surface soil samples $(\mathrm{O}-15 \mathrm{~cm}$ depth) were taken randomly from the experimental sites. The samples were bulked, air dried and sieved using a $2 \mathrm{~mm}$ sieve and analyzed for particle size, soil organic matter total $\mathrm{N}, \mathrm{P}, \mathrm{K}, \mathrm{Ca}$, $\mathrm{Mg}$ and $\mathrm{pH}$. The samples were taken, bulked and sub sampled as described by Carter (1993). Particle size analysis was done using hydrometer method (Bouyoucos, 1962) while organic matter was determined by the procedure of Walkley and Black using the di -chromate wet oxidation method (Nelson and Sommers, 1982). Total N was determined by micro - Kjeldahl digestion method (Bremner, 1965) and available $\mathrm{P}$ was by Bray - 1 extraction followed by molybdenum blue colorimetry (Bray and Kurtz, 1945). Exchangeable $\mathrm{K}, \mathrm{Ca}$ and $\mathrm{Mg}$ were extracted by EDTA titration method (Jackson, 1962). Soil pH was determined in 1:2 soils water ratio using digital electronic $\mathrm{pH}$ meter. Cow dung was obtained form Obaba Farms, Ponyan. Samples from these cow dung materials were taken for laboratory analysis in other to determine nutrient composition. The samples were air dried, crushed, passed through a $2 \mathrm{~mm}$ sieve before analysis. The samples were analysed for organic $\mathrm{C}, \mathrm{N}, \mathrm{P}, \mathrm{K}, \mathrm{Ca}$ and $\mathrm{Mg}$ contents

Data taken included plant height at $50 \%$ flowering, number of branches per plant, leaf area, pod length, pod diameter, number of pods per plant, pod weight and yield ( $t / h a)$. The data were subjected to Analysis of Variance (ANOVA) while the Least Significant Difference (LSD) was used to separate treatment means following the procedure of Steel and Torrie (1980)

\section{Results and Discussion}

\subsection{Soil Analysis and Organic Material Used}

The soil was $64.7 \%$ sand, $20.3 \%$ clay and $15.0 \%$ silt, slightly acidic (pH 5.8) and with a total $\mathrm{N}$ content of $0.24 \%$. Available phosphorus was $0.92 \mathrm{mg} \mathrm{kg}^{-1}$ and exchangeable potassium was $0.24 \mathrm{mg} \mathrm{kg}^{-1}$, contents of $\mathrm{Ca}$ and $\mathrm{Mg}$ were 2.01 and $2.63 \mathrm{cmol} / \mathrm{kg}$ respectively (Table 1 ). The chemical composition of cow dung revealed that it had a $\mathrm{pH}$ of 6.4 , total nitrogen content of $3.6 \%, 1.87 \%$ available $\mathrm{P}, 38.4 \%$ organic carbon, $3.14 \%$ available $\mathrm{K}$ and $\mathrm{C} / \mathrm{N}$ ratio of $10.6 \%$ (Table 2). Fertilizer and manure are one of the most important inputs contributing to crop production because it increases productivity and improve yield quality and quantity. The general low ambient soil nutrient content made the soil suitable for study of response to fertilizer.

\subsection{Effect of Cow Dung and Foliar Fertilizer on Growth Component of Okra}

Nutrients supplied in the form of cow dung and foliar fertilizer alone or in combination, affect okra plant height, stem girth, number of leaves produced and leaf area (Table 3). Plants treated with $1.5 \mathrm{l} / \mathrm{ha}$ foliar fertilizer plus $2 \mathrm{t} / \mathrm{ha}$ cow dung had the tallest plants. Plots with $11 /$ ha foliar $+2.5 \mathrm{t} /$ ha cow dung and $21 /$ ha foliar $+1.5 \mathrm{t} /$ ha cow dung produced plants with comparable heights. Sole application of both foliar fertilizer and cow dung had shorter plants that were similar in height. 
Stem girth was affected by treatment (Table 3). Plants with combined application of cow dung and foliar fertilizer had taller plants compared to plants with sole application of either foliar fertilizer or cow dung. Plants with 1.51 / ha foliar fertilizer $+2 \mathrm{t} / \mathrm{ha}$ cow dung, $2 \mathrm{l} / \mathrm{ha}$ foliar $+1.5 \mathrm{t} / \mathrm{ha}$ cow dung had similar girth. The least stem girth was observed in plants treated with $3 \mathrm{t} / \mathrm{ha}$ cow dung alone.

Okra plant leaf area was highest in plant treated with $21 /$ ha foliar fertilizer $+1.5 \mathrm{t} / \mathrm{ha}$ cow dung (Table 3). However, this was not significantly different from plots with 1 1/ha foliar + $2.5 \mathrm{t} / \mathrm{ha}$ cow dung, $1.5 \mathrm{l} / \mathrm{ha}$ foliar $+2 \mathrm{t} / \mathrm{ha}$ cow dung and plants with $2.51 / \mathrm{ha}$ foliar $+1 \mathrm{t} / \mathrm{ha}$ cow dung. Plants with foliar alone and cow dung residue alone were smaller and similar.

These results are in agreement with that of Alston (1979) who reported better vegetative growth of crop with foliar application of N. Similar, Soyln et al., 2005; Kenbear and Sade (2002) and Arif et al., (2006) reported significant increase in plant height, stem girth and leaf area of crop with foliar application of different nutrients individually or in combination. The result of this findings support the earlier results. The combination of cow dung materials with foliar produced plants those were similar. This indicated that the high dose of organic manures can be reduced by half and mix with reduced rate of inorganic fertilizer (foliar). The nutrient use efficiency of crops is better with a mix of manure and inorganic fertilizer (Murwira and Keirehmann, 1993). Nutrients seemed more available to Okra plants with the mixes then either cow dung or foliar fertilizer alone.

\subsection{Effect of Cow Dung and Foliar Fertilizer on Yield and Yield Components of Okra}

Number of Okra fruit per plant, length of okra fruit and average weight of okra fruit were lowest in plants treated with $3 \mathrm{t}$ of cow dung per ha. The highest fruit number was from application of $2.51 /$ ha foliar $+1 \mathrm{t} / \mathrm{ha}$ cow dung, this was not statically better than plants with application of $2 \mathrm{l} / \mathrm{ha}$ foliar $+1.5 \mathrm{t} / \mathrm{ha}$ cow dung. Okra fruit yield was lowest for the plants treated with cow dung alone $(0.24 \mathrm{t} / \mathrm{ha})$. Yield form plants treated with combined use of cow dung and foliar fertilizer were similar and significantly higher than either plants with cow dung alone or foliar application alone. Among the treatments, plants treated with 2 .0t of foliar $+1.5 \mathrm{t}$ or cow dung recorded the greatest yield. However, the yield was not statistically better than plot treated with 2.51 of foliar fertilizer +1 t or cow dung per ha $=($ Table 5$)$.

Foliar fertilization gave significant higher fruits yields. Application of a mix or organic manure (Cow dung) and inorganic fertilizer can be used to sustain okra in the tropics. A similar trend of response had been earlier observed with other crops such as maize (Makinde and Ayoola., 2008); Sorghum (Bayu et al., 2000); and wheat (Parvez et al., 2009).

\section{Conclusion}

Field experiment was carried out at Kabba on responses of okra yield to organic manure and inorganic foliar fertilizer the experiment consist of six treatments which are $0 \mathrm{~L} / \mathrm{ha}$ foliar + $3 \mathrm{t} /$ ha cow dung, 1.0L/ha foliar $+2.5 \mathrm{t} / \mathrm{ha}$ cow dung, $1.5 \mathrm{~L} / \mathrm{ha}$ foliar $+2 \mathrm{t} / \mathrm{ha}$ cow dung, $2 \mathrm{~L} / \mathrm{ha}$ foliar $+1.5 \mathrm{t} /$ ha cow dung, $2.5 \mathrm{~L} / \mathrm{ha}$ foliar $+1 \mathrm{t} / \mathrm{ha}$ cow dung and $3 \mathrm{~L} / \mathrm{ha}$ foliar $+0 \mathrm{t} / \mathrm{ha}$ cow dug. The result shows that plot treated with $2.0 \mathrm{~L} / \mathrm{ha}$ foliar $+1.5 \mathrm{t} / \mathrm{ha}$ cow dung had the best performance in yield and yield components in this study. It is therefore recommended that 


\section{Macrothink}

Journal of Agricultural Studies

ISSN 2166-0379 2016, Vol. 4, No. 1

okra farmers should integrated foliar fertilizer (boost extra) at the rate of $2 \mathrm{~L}$ per hectare with cow dung at rate of $1.5 \mathrm{t}$ per hectare be used for okra production in the study area.

Table 1. Properties of soil before the experiment in 2014.

\begin{tabular}{ll}
\hline Particle Size & Percentage $(\%)$ \\
\hline Sand & 64.7 \\
Clay & 20.3 \\
Sit & 15.0 \\
Soil Texture & Sandy Clay Loam \\
pH (H $\left.{ }_{2} 0\right)$ & 5.8 \\
Total N & 0.24 \\
Available p (mg/kg & 0.36 \\
& \\
Exchangeable Cation $(\mathrm{Cmol} / \mathrm{kg}$ & \\
$\mathrm{K}$ & 2.63 \\
Ca & 0.24 \\
Mg & 2.01 \\
\hline
\end{tabular}

Table 2. Chemical properties of cow dung used

Chemical properties

Orgianic carbon

Total N

$\mathrm{C} / \mathrm{N}$

Phosphorus

Potassium

Calcium

Magnesium

Soil pH
(\%)

38.4

3.60

10.6

1.87

3.14

1.22

0.31

6.4 
Table 3. Effects of cow dung and foliar fertilizer on growth component of okra (mean of two years).

\begin{tabular}{ccccc} 
Treatment & $\begin{array}{c}\text { Average plant } \\
\text { height }(\mathbf{c m})\end{array}$ & $\begin{array}{c}\text { Number of } \\
\text { leaves }\end{array}$ & $\begin{array}{c}\text { Stem } \\
\text { diameter }(\mathbf{c m})\end{array}$ & $\begin{array}{c}\text { Leaf area } \\
\left(\mathbf{m}^{2}\right)\end{array}$ \\
\hline A & $18.68^{\mathrm{c}}$ & $16.02^{\mathrm{a}}$ & $2.34^{\mathrm{a}}$ & $90^{\mathrm{b}}$ \\
$\mathrm{B}$ & $26.31^{\mathrm{ab}}$ & $18.31^{\mathrm{a}}$ & $2.63^{\mathrm{ab}}$ & $105^{\mathrm{a}}$ \\
$\mathrm{C}$ & $31.86^{\mathrm{a}}$ & $18.42^{\mathrm{a}}$ & $2.86^{\mathrm{a}}$ & $108^{\mathrm{a}}$ \\
$\mathrm{D}$ & $29.41^{\mathrm{ab}}$ & $16.94^{\mathrm{a}}$ & $2.82^{\mathrm{a}}$ & $112^{\mathrm{a}}$ \\
$\mathrm{E}$ & $22.43^{\mathrm{bc}}$ & $17.45^{\mathrm{a}}$ & $2.61^{\mathrm{ab}}$ & $94.6^{\mathrm{ab}}$ \\
$\mathrm{F}$ & $18.64^{\mathrm{c}}$ & $18.21^{\mathrm{a}}$ & $2.53^{\mathrm{b}}$ & $77^{\mathrm{c}}$ \\
\hline
\end{tabular}

In a column, figures bearing same letter(s) do not differ significantly at 5\% level of probability by DMRT. A $=3 \mathrm{t} / \mathrm{ha}$ cow dung, $\mathrm{B}=1 \mathrm{1} / \mathrm{ha}$ foliar $+2.5 \mathrm{t} / \mathrm{ha}$ cow dung, $\mathrm{C}=1.51 / \mathrm{ha}$ foliar $+2 \mathrm{t} / \mathrm{ha}$ cow dung, $\mathrm{D}=2 \mathrm{1} / \mathrm{ha}$ foliar $\quad+1.5 \mathrm{t} / \mathrm{ha}$ cow dung, $\mathrm{E}=2.5 \mathrm{l} / \mathrm{ha}$ foliar + $1 \mathrm{t} /$ ha cow dung, $\mathrm{F}=3 \mathrm{t} / \mathrm{ha}$ foliar.

Table 4. Effect of application of cow dung and foliar fertilizer on yield and yield component of okra (mean of two years).

\begin{tabular}{cllll}
\hline Treatment & $\begin{array}{c}\text { Number of } \\
\text { fruit/plant }\end{array}$ & $\begin{array}{c}\text { Length of } \\
\text { fruits (cm) }\end{array}$ & $\begin{array}{c}\text { Fruit } \\
\text { diameter (cm) }\end{array}$ & $\begin{array}{c}\text { Average } \\
\text { weight of } \\
\text { fruit (g) }\end{array}$ \\
\hline A & $6.2^{\mathrm{c}}$ & $5.8^{\mathrm{a}}$ & $3.2^{\mathrm{b}}$ & $0.71^{\mathrm{b}}$ \\
$\mathrm{B}$ & $7.4^{\mathrm{b}}$ & $6.1^{\mathrm{bc}}$ & $3.3^{\mathrm{ab}}$ & $0.76^{\mathrm{b}}$ \\
$\mathrm{C}$ & $7.6^{\mathrm{b}}$ & $6.3^{\mathrm{b}}$ & $3.10^{\mathrm{b}}$ & $0.91^{\mathrm{a}}$ \\
$\mathrm{D}$ & $8.3^{\mathrm{a}}$ & $7.4^{\mathrm{a}}$ & $3.1^{\mathrm{b}}$ & $0.94^{\mathrm{a}}$ \\
$\mathrm{E}$ & $9.8^{\mathrm{a}}$ & $6.2^{\mathrm{b}}$ & $3.6^{\mathrm{a}}$ & $0.85^{\mathrm{c}}$ \\
$\mathrm{F}$ & $7.4^{\mathrm{b}}$ & $6.5^{\mathrm{b}}$ & $3.1^{\mathrm{b}}$ & $0.78^{\mathrm{b}}$ \\
\hline
\end{tabular}

In a column, figures bearing same letter(s) do not differ significantly at 5\% level of probability by DMRT. A $=3 \mathrm{t} / \mathrm{ha}$ cow dung, $\mathrm{B}=1 \mathrm{l} / \mathrm{ha}$ foliar $+2.5 \mathrm{t} / \mathrm{ha}$ cow dung, $\mathrm{C}=1.51 / \mathrm{ha}$ foliar $+2 \mathrm{t} /$ ha cow dung, $\mathrm{D}=2 \mathrm{l} / \mathrm{ha}$ foliar $\quad+1.5 \mathrm{t} / \mathrm{ha}$ cow dung, $\mathrm{E}=2.5 \mathrm{1} / \mathrm{ha}$ foliar + $1 \mathrm{t} /$ ha cow dung, $\mathrm{F}=3 \mathrm{t} / \mathrm{ha}$ foliar. 


\section{Macrothink}

Journal of Agricultural Studies

ISSN 2166-0379

2016, Vol. 4, No. 1

Table 5. Effect of application of cow dung and foliar fertilizer on yield and yield component of okra continued (mean of two years).

\begin{tabular}{lll} 
& Fruit weight/plant $(\mathbf{g})$ & Yield t/ha \\
\hline A & $4.41^{\mathrm{c}}$ & $0.24^{\mathrm{c}}$ \\
B & $5.40^{\mathrm{b}}$ & $0.30^{\mathrm{bc}}$ \\
C & $6.92^{\mathrm{ab}}$ & $0.38^{\mathrm{ab}}$ \\
D & $7.80 \mathrm{a}$ & $0.43^{\mathrm{a}}$ \\
E & $7.48^{\mathrm{a}}$ & $0.42^{\mathrm{a}}$ \\
F & $5.77^{\mathrm{b}}$ & $0.32^{\mathrm{b}}$ \\
\hline
\end{tabular}

In a column, figures bearing same letter(s) do not differ significantly at $5 \%$ level of probability by DMRT. $\mathrm{A}=3 \mathrm{t} / \mathrm{ha}$ cow dung, $\mathrm{B}=1 \mathrm{1} / \mathrm{ha}$ foliar $+2.5 \mathrm{t} / \mathrm{ha}$ cow dung, $\mathrm{C}=1.51 / \mathrm{ha}$ foliar $+2 \mathrm{t} /$ ha cow dung, $\mathrm{D}=2 \mathrm{1} / \mathrm{ha}$ foliar $\quad+1.5 \mathrm{t} / \mathrm{ha}$ cow dung, $\mathrm{E}=2.5 \mathrm{l} / \mathrm{ha}$ foliar + $1 \mathrm{t} /$ ha cow dung, $\mathrm{F}=3 \mathrm{t} / \mathrm{ha}$ foliar.

\section{References}

Abou El-Magd, M., Hoda, M., Mohammed, A., \& Fawzy, Z. F. (2005). Relationship N. P or K Ratio in a Mixture of NPK Fertilizers. Annuals Agriculture Science Moshtohor, 43(2), 791-805.

Agbo, A. E., Gnakri, D., Beugre G. M., Fondio L, Kouame, C (2008). Maturity degree of four okra fruit varieties and their nutrients composition. Elect. J. Food Plant Chem, 5, 1-4.

Alston, A. M. (1979). Effects of Soil Water Content and Foliar Fertilization with Nitrogenand Phosphorus in Late Seasons on the Yield and Composition of Wheat. Aus. J. Exper. Agric., 30(4), 577-585.

Alasiri, K.O., \& Ogunkeye, O. O. (1999). Effect of Different Levels of Poultry Manure on Seed Yield of Okra. Proceedings $25^{\text {th }}$ Annual Conference of Soil Science Society of Nigeria, $21^{\text {st }}-25^{\text {th }}$ November, 1999. Benin, Nigeria.

Alexander M, Srikantha I, Kumar M. Y., Natesan S, \& Mithyanta M. S. (2004). Effects of application of boron and calcium on yield and shelf life of tomato (Lycopersicumesculentum). IFA, International symposium on micronutrients, 22-25. Feb. 2004, New Delhi, India.

Arif, M., Chohan, M. A. Ali, S. Gul, R., \& Khan, S. (2006). Response of Wheat to foliar Application of Nutrients. J. Agric and Bio. Sci., 4, 30-34.

Arapitsas P. (2008). Identification and quantification of polyphenolic compounds from okra seeds and skins. Food Chem, 110, 1041-1045.

Ayuso, M. A., Pascal, J. A., Garcia C., \& Hemandez. (1996). Evaluation of Urban Waste for 
Agricultural use. Soil Science Plant Nutrition, 42, 105-111.

Barge, G. L. (2001). Foliar fertilizer application for soybean production. Special Circular, 197, $71-73$

Bayu, W., Rethman N. F. G., \& Hammers, P. S. (2006). Effect of Inorganic Fertilizers on Sorghum Growth, Yield and Nitrogen use in a Semi Arid Area of Ethiopia J. Plant Nutrition, 29, 391-407.

BeMiller J. N., Whistler, R. L., Barkalow, D. G., Chen, C. C. (1993). Aloea, chia, flax seed, okra, psyllium seed, quince seed, and tamarin gums. In: Industrial Gums, Whistler RL, BeMiller JN (eds.), Academic Press, New York, 227-256.

Bray, R. H., \& Kurtz, L. T. (1965) Determination of total organic and available forms of phosphorus in soil. Soil Science, 59, 225-62427.

Bremner, J. M. (1965). Regular micro - Kjeldahl method for determination of total nitrogen. In Black, C.A. (eds), methods of soil analysis, part 2. American Society of Agronomy No. 9 Madison WI, 1149 - 1176.

Bouyoucos, G. O. (1962). Hydrometer method improved for making particles size analysis of soils. Agronomy Journal, 54, 464 - 465.

Carter, M. R. (1993). Soil sampling and methods of analysis. Canadian Society of Soil Science, Lewis publisher London, 823.

El-shakweer, M. H. A., El-Sayed, E. A., \& Ewees, M. S. A. (1998). Soil and Plant Analysis as a Guide for Interpretation of the Improvement Efficiency of Organic Conditioners Added to Different Soil in Egypt. Communication Soil Science Plant Anal., 29, 2067-2088.

Fageria, N. K. (2007). Soil Fertility and Plant Nutrition Research under Field Conditions: Basic Principles and Methodology. Journal of Plant Nutrition, 30, 203-223.

Fageria, N. K., Barbosa Filho M. P., Moreira, A., \& Guimaraes, C. M. (2009). Journal of plant nutrition, 32, 1044 -1064. HTTP://DX.DOI.ORG/1080/01904160902872826.

Fritz, A. 1978. Foliar Fertilization -A Technique for Improved Crop Production. Acta Horticulture, 84, 43-56.

George RAT (1999). Vegetables seed production. second edition, CABI Publishing, 329.

Girma, K., Martin, K. L., Freeman, K. W., Mosali, J., Teal, R. K., Raun, W. R., Moges, S. M., \& Arnall, D. B. (2007). Determination of Optimum rate and Growth for Foliar Applied Phosphorus in Corn. Communications in Soil Science and Plant Analysis, 38, 1137-1154.

Haq, M. U., \& A. P. Mallarino. 2000. Soybean Yield and Nutrient Composition as Affected by Early Season Foliar Fertilization. Agronomy Journal, 92, 16-24.

Iyagba A.G, Onuegbu, B.A \& IBE, A.E. (2012). Growth and Yield Response of Okra (Abelmoschus esculentus (L.) Moench) Varieties to Weed Interference in South-Eastern 
Nigeria. Global Journal of Science Frontier Research Agriculture and Veterinary Sciences, 12(7), $23-31$.

Jackson, M. L. (1962). Soil chemical Analysis. Practices - Hall Endewood Cliffs, New Jersey, 491-498.

Kendall, C. W. C., Jenkins, D. J. A. (2004). A dietary portfolio: maximal reduction of low-density lipoprotein cholesterol with diet. Current Atherosclerosis Reports, 6,492-49

Kenbaev, B., \& Sade, B. (2002). Response of Field -Grown barley Cultivars Grown on Zinc-Deficient Soil to zinc Application. Comm. Soil Sci. Plant Anal., 33(3-4), 533-544.

Kumar, R., Patil, M. B., Patil, S. R., Paschapur, M. S. (2009). Evaluation of Abelmoschus esculentus mucilage as suspending agent in paracetamol suspension. Intl. J. Pharm. Tech. Res., $1,658-665$.

Lengsfeld, C., Titgemeyer, F, Faller, G., \& Hensel, A. (2004). Glycosylated compounds from okra inhibit adhesion of Helicobacter pylori to human gastric mucosa. J. Agric. Food Chem., $52,1495-1503$.

Makinde, E. A., \& Ayoola, A. A. (2008). Residual Influence of Early Season Crop Fertilization and Cropping System on Growth and Yield of Cassava American J. of Agric. and Biological Science, 3(4), 712-715.

Masto, R. E., Chhonkar, P. K., Singh, D., \& Patra, A. K. (2007). Soil quality response to long-term nutrient and crop management on a semi-arid Inceptisol. Agric. Ecosyst. Environ, $118,130-142$.

Muriwira, H., \& Krichmann, H. (1993). Carbon and nitrogen mineralization of cattle in Zimbabwean and swedish soils in Mulongoy and R. merckk (eds) Soil Organic matter dynamics and sustainability of tropical agriculture. John Wiley and Son's, 392.

National Academies Press (2006). Lost Crops of Africa Volume II: Vegetables. www.nap.edu/catalog/11763.html; 287-301.

Nelson, D. W., \& Sommers, L. E. (1982). Total carbon, organic carbon and organic matter. In: page A.L, Miller R.H. and Keenay, D.R. (Eds) Methods of soil Analysis, part 2 ASA, Madison, WI, 539 - 580.

Olayinka, A., \& Ailenubhi, V. (2001). Influence of combined application of cow dung and inorganic nitrogen fertilizer on microbial respiration and nitrogen transformation in an alfisol. Nigerian Journal soil research, 2, $15-20$.

Ofoefule, S. I., Chukwu, A. N., Anayakoha A., \& Ebebe I. M. (2001). Application of Abelmoschus esculentus in solid dosage forms 1: use as binder for poorly water soluble drug. Indian J. Pharm. Sci, 63, 234-238.

Parvez, K., Muhammed, Y. M., Muhammad, I., \& Muhammad, A. (2009). Response of Wheat to Foliar and Soil Application of Urea at Different Growth Stages. Pak. J. Bot., 41(3), $11-1204$. 


\section{Macrothink}

Selvi, D., \& Rani, P. (2000). Effects of integrated nutrient management on yield and economics of okra in an inceptisol. Veg. Sci. 27(2), 207-208.

Sharma, A. R., \& Mittra, B. N. (1991). Journal of Agricultural Science, 117, 313 - 318.

Smil, V. (2000). Phosphorus in the Environment: Natural Flows and Human Interferences. Annual Review of Energy and Environment, 25, 53-88

Soylu, S., Sade, B., Topal, A., Akgun, N., \& Gezgin, S. (2005). Responses of Irrigated Durum and Bread Wheat Cultivars to Boron Application in Low Boron Calcareous soil. Turk. J. Agric., 29, 275-286.

Steel R. G. D., \& Torrie, J. H. (1980). Principles and procedures of statistics: a biological yield approach, 2nd ed. McGraw Hill Book Co., Inc. New York.

Vanlauwe, B., Wendt, J. W., \& Diels, J. (2001). Combined application of organic matter and fertilizer. Journal of American Society of Agronomy, 50, 247.

Yadev R. L., \& Prasad, S. K. (1992). Conserving the organic matter content of the soil to sustain sugar cane yield and uptake by sugar cane. Bharatiya sugar, 18, $15-23$.

Zhao, A., Wang, P., Li, J., \& Chen, X. Y. (2009). The effects of two organic manures on soil properties and crop yields on temperate calcareous soil under wheat-maize cropping system. European j. Agron, 31, 36-42.

\section{Copyright Disclaimer}

Copyright for this article is retained by the author(s), with first publication rights granted to the journal.

This is an open-access article distributed under the terms and conditions of the Creative Commons Attribution license (http://creativecommons.org/licenses/by/3.0/). 